UDC 339.138

JEL Classification: M15, 032

\author{
Davidavičienė Vida \\ Dr. of Sc. (Management), Professor
}

Head of the Department of Business Technologies and Entrepreneurship

Vilnius Gediminas Technical University

(Vilnius, Lithuania)

Fadwa Chalfoun

Mgr of Sc. (Management)

PhD student of the Department of Business Technologies and Entrepreneurship

Vilnius Gediminas Technical University

(Vilnius, Lithuania)

\title{
SOCIAL MEDIA NETWORKS USE IN COMMUNICATION ANALYSES OF ARABIC COUNTRIES
}

The development of social media is changing the ways of communicating, collaborating, creating and consuming. Social networks become fundamental and have a transformative impact on business and companies. The use of social network tools, and stimulating innovation in relationship with buyer and potential customer help to increase communication and interaction. The target of this article is analyze, identify, and to show all the particularities of social media networks use in Arabic countries. The methods used are scientific literature analysis, cross table analysis and comparison analyzes.

Keywords: social media, digital media, marketing communication, social networks.

\section{DOI: 10.15276/mdt.2.2.2018.1}

Statement of the problem in general form and it's connection with important scientific or practical tasks. Over the past decade, social media networks in marketing communications has exhibited and exponential integration and penetration into lives of individuals and businesses. It became an indispensable and needed necessity for daily life [1]. The network of social media permit the creation of online communication among communities and encourage the participation of users with different media models [2]. With the rising of social media, all Arabic world users, hold the new technology by utilizing social media tools in order to communicate rapidly and fast [3]. Thus, business is becoming the leading position of the social media to found and create an effective presence [1]. Companies can thru social media tools, connect, publicize, promote and advertise their products and services with their customers [4]. Moreover, Arab governments require the meaning and importance of social media. Using social media tools in Arab countries support the communication between the population, the business and the government [5]. Arab world users create new usage for many channels connecting with the online world [6]. Social media use in Arab countries has more potential to grow as well as in Africa in comparison with Europe or North America.

Social media Networks remain the set of online applications which construct the basic beliefs and guiding principles that manifest ideas and techniques through Websites. Thus, it means the connection between people in which they are trading, creating, exchanging and sharing information and thoughts in virtual networks. Also, it is a classification and varieties of new set of online media for involvement, acceptance, broad-mindedness and discourse. [7]. 
Therefore, this topic was selected as a consequence of the growing rising and widening increase of the channels of social networks. Hence, social media in Arab Countries has several impacts [8].

Most of these impacts are:

- shortening distances between people;

- immediate and direct platform to get information and news;

- offers features, products and services;

- offers opportunities for jobs and careers;

- enable the growth and expansion of businesses with direct revenue generation;

- improve corporate image and mission;

- large platform of advertising and marketing that encourage consumer approaches.

Despite of all these advantages, Arab countries suffer from non-conductive of personnel interaction between users and risk of ruination of corporate reputation. Thus, social media channels may pose a big threats to traditional media and may take a piece of their market shares [9]. Therefore, for the organization it is very important to choose the social network that will deliver the message to the target audience (Davidavičienè, 2017). Companies must represent themselves in the online world in order to be more active so it is very essential to appreciate and understand changes and in marketing communication affected by the growth and rise of social network channels.

Formulation of the purpose of the article (statement of the problem) is to show, consider, analyze, and identify the particularities of networks of social media in Arabic countries. The methods used are scientific literature analysis, cross table analysis, and comparison analyzes.

Analysis of the latest research and publications, which initiated the solution of this problem and on which the author relies. Moreover, Social media in communication is very important in all fields and domains. It should be understood by defining Web2.0 which is described as an advanced and courant approach for the World Wide Web, a very large position and area where everything can be successively and constantly alerted through users by sharing information [10]. «It is much more to do with what people are doing with the technology than the technology itself, for rather than merely retrieving information, users are now creating and consuming it, and hence adding value to the websites that permit them to do so» [11]. The demonstration of definitions of scientist about Social Media in Communication internet penetration by country is represented in Table 1 .

Table 1 - Definitions of scientist about Social Media in Communication

\begin{tabular}{|l|c|c|}
\hline \multicolumn{1}{|c|}{ Definitions } & Scientists & \multicolumn{1}{c|}{ Article } \\
\hline $\begin{array}{l}\text { The bottom line of social media networks is the capability } \\
\text { and competency to partage and hold contain with users. In } \\
\text { consideration of uploading content, users record and register } \\
\text { their profiles by creating them }\end{array}$ & {$[12]$} & $\begin{array}{l}\text { The value and use of social } \\
\text { media as communication tool } \\
\text { in the plant sciences }\end{array}$ \\
\hline $\begin{array}{l}\text { Social Media Networks is a platform that show services and } \\
\text { permit users to build public profiles through systems, and } \\
\text { remain lists of other users with whom they share information } \\
\text { and connection. The nature of connection may vary from site } \\
\text { to site }\end{array}$ & {$[13]$} & Social network sites \\
\hline $\begin{array}{l}\text { The platform of internet shows a progressively big toolbox, } \\
\text { and it may be hard to select between varieties of «core } \\
\text { resources» }\end{array}$ & {$[14]$} & $\begin{array}{l}\text { An Introduction to Social } \\
\text { Media for Scientists }\end{array}$ \\
\hline
\end{tabular}

V. Davidavičiene, F. Chalfoun. Social media network use in communication analyses of 
Continued Tab 1

\begin{tabular}{|c|c|c|}
\hline $\begin{array}{l}\text { The research work is affected by the tools of social media. } \\
\text { The scholar discussions are growing increasingly and shared } \\
\text { all over webs like twitter, Mendeleye and zotero. Discussions } \\
\text { may be reviewed by comments and suggestions }\end{array}$ & [15] & $\begin{array}{l}\text { Altmetrics in the Wild: Using } \\
\text { Social Media to Explore } \\
\text { Scholarly Impact }\end{array}$ \\
\hline $\begin{array}{l}\text { The social media data is readable in a special machine that } \\
\text { opens new perspectives and experiences for social networks } \\
\text { analyses }\end{array}$ & [16] & $\begin{array}{l}\text { Semantic Social Network } \\
\text { Analysis }\end{array}$ \\
\hline $\begin{array}{l}\text { Recently, the sites of social media is the most popular and } \\
\text { much known purposes and destinations. The high level of } \\
\text { users is covered by press and speculation about all terms of } \\
\text { social network sites }\end{array}$ & [17] & $\begin{array}{l}\text { Who's Space? Differences } \\
\text { Among Users and Non-Users } \\
\text { of Social Network Sites }\end{array}$ \\
\hline $\begin{array}{l}\text { Some arguments supported by science outreach social media } \\
\text { are simply applications of arguments }\end{array}$ & [18] & $\begin{array}{l}\text { A critical evaluation of science } \\
\text { outreach via social media: its } \\
\text { role and impact on scientists }\end{array}$ \\
\hline $\begin{array}{l}\text { About tweets, they can expect and predict cited articles } \\
\text { between the three days of the publications of articles. The } \\
\text { activity of social media can increase progressively citations } \\
\text { and reflects the quality of the articles that predict citations but } \\
\text { the main true use of this criterion is to measure the impact of } \\
\text { social media use }\end{array}$ & {$[15]$} & $\begin{array}{l}\text { Can Tweet predict citations? } \\
\text { Metrics of social impact based } \\
\text { on Twitter and correlation with } \\
\text { traditional metrics if scientific } \\
\text { impact. }\end{array}$ \\
\hline $\begin{array}{l}\text { Basically, the online social network is where a community } \\
\text { interact, cooperate and relate through their profiles that show } \\
\text { and represent their public personnel and networks of } \\
\text { connection }\end{array}$ & [19] & $\begin{array}{l}\text { Imagined Communities: } \\
\text { Awareness, Information } \\
\text { Sharing, and Privacy on the } \\
\text { Facebook }\end{array}$ \\
\hline $\begin{array}{l}\text { Taking into consideration the methods of growing the social } \\
\text { media over time, in an individual and community level, it can } \\
\text { change and advance membership and content }\end{array}$ & {$[20]$} & $\begin{array}{l}\text { Group Formation in Large } \\
\text { Social Networks: Membership, } \\
\text { Growth, and Evolution }\end{array}$ \\
\hline $\begin{array}{l}\text { The big evolution of the Internet has taken to live and online } \\
\text { communities, that allow persons to found and preserve } \\
\text { numerical and digital networks with other users }\end{array}$ & [21] & $\begin{array}{l}\text { Stoichiometric Attractiveness } \\
\text { on Facebook }\end{array}$ \\
\hline $\begin{array}{l}\text { The sites of social network are becoming popular and much } \\
\text { known recently. Thus, they attract the attention of } \\
\text { researchers. Greatest of the readings directed to date have } \\
\text { concentrated on a only societal interacting site }\end{array}$ & [22] & $\begin{array}{l}\text { Trust and privacy concern } \\
\text { within social networking sites: } \\
\text { A comparison of Facebook and } \\
\text { Myspace }\end{array}$ \\
\hline $\begin{array}{l}\text { Friendster, World, My space and others networks sites let } \\
\text { users presenting themselves and connecting by social } \\
\text { networks and establish by maintaining communication with } \\
\text { others }\end{array}$ & [13] & $\begin{array}{l}\text { The Benefits of Facebook } \\
\text { «Friends:» Social Capital and } \\
\text { College Students' Use of } \\
\text { Online Social Network Sites }\end{array}$ \\
\hline $\begin{array}{l}\text { Studying social networks observes many levels and relate } \\
\text { them. Researchers has examined the manner of how } \\
\text { individuals make friends and how much they rely to each } \\
\text { other's in their social network support }\end{array}$ & {$[23]$} & $\begin{array}{l}\text { Rhythms of social interaction: } \\
\text { messaging within a massive } \\
\text { online network }\end{array}$ \\
\hline $\begin{array}{l}\text { Social network analysis offers a powerful background for } \\
\text { observing and understanding common relations connected. } \\
\text { They are complemented by a multitude of logical methods } \\
\text { ranging from simple importance marks to sophisticated } \\
\text { models }\end{array}$ & [24] & $\begin{array}{l}\text { Analyzing Social Networks Via } \\
\text { the Internet }\end{array}$ \\
\hline
\end{tabular}

Statement of the main material of the research with full justification of the scientific results obtained. Arab countries and regions took big steps and cross phases to reach and adopt frequently e-business, e-commerce and e-marketing [25] through all social medias tools networking. Arabic countries are becoming significant online marketplaces and powerhouses where they can integrate and penetrate commerce and marketing concerns [26]. The demonstration of internet penetration by country is represented in Table 2 . 
Table 2 - Internet penetration by country

\begin{tabular}{|c|cccccc|}
\hline YEAR & UAE & QATAR & KSA & LEBANON & TUNISIA & EGYPT \\
\hline 2013 & $88 \%$ & $85 \%$ & $81 \%$ & $58 \%$ & NO DATA & $22 \%$ \\
2014 & $96 \%$ & $78 \%$ & $85 \%$ & $62 \%$ & $45 \%$ & $36 \%$ \\
2015 & $94 \%$ & $91 \%$ & $89 \%$ & $79 \%$ & $44 \%$ & $45 \%$ \\
2016 & $100 \%$ & $93 \%$ & $93 \%$ & $84 \%$ & $49 \%$ & $59 \%$ \\
\hline
\end{tabular}

Source: Internet Live Stats (2017) (www.internetlivestats.com)

Moreover, by increasing and focusing on social media networks in marketing communication, companies can succeed by considering each Arab country levels in many fields: geopolitical, cultural, linguistic, connection appliances and employments. There are many and various tools that are in practice as social media forms in Arab countries. SNS (social network sites) are the simulated societies allowing individuals to build profiles, join with others, share information thru communicating and connecting [27]. The main common SNS are Facebook, Google+, LinkedIn, Myspace, etc.

Blogs are personnel web that are written by a user concerning a certain topic and wants to share with the community of readers who can write comments, like or feedback. Blogs are also considered as online journals that are widely used and popular because they provide specifics topics [28]. Content communities are sites that can allow and let users write, post and share content. They are existed around videos, links and others. Some content communities such like YouTube can simplify the process of commenting and sharing on music and videos [9]. Forums are platforms where all users create topics with its comments. Forums are considered as resources for those who are interested in special topics [29]. Forums permit the discussion online with same and similar interest and notice. They are a big powerful element of online communities. Sometimes, forums are as well know chat rooms or messages boards. Virtual words are commonly known as the novel area on the web usage. User can engage, involve and occupy immersive worlds [1]. Databases and document are generated and created by Wikis users. Wikis website let users add, edit, acting on information. It seems like working on a database. The best wikis known are Wikipedia, the encyclopedia used online with over 2 million English languages articles; Wiki travel, the free travel guide; etc. Mini (micro) blogging present social media interacting shared with blogs. Updates of enclosures are spread through online mobiles networks; the application of «Twitter» is considered as a familiar mini blog. Social bookmarking also are platforms that reflect online new stories where users can simply recommend online music, videos, vote and others interested topics to focus on.

In Arab countries, all these social media networks start to have numerous aspects and improve the real quality of business that lead the profitability and success. The governmental relation with public seems successful and effective [30]. Recent Arabic statistics organized by the Arab Social Media Influencers Summit (2015) stated that $81 \%$ consider social media as easier way to connect, $51 \%$ reflect that it is a great channel of communication between the public and the government [31]. Otherwise, the most Arab country primarily practice channels and tools of social media to connect and join each other's. Chatting, gaining information, listening to music, watching videos, sharing photos and images, all are habits for Arab users but chatting is the most common activity among them [32]. Facebook is one of the furthermost practiced used of social media channels across Arabic countries [27]. In one hand, 
a part of users occupy about half an hour per session of usage of internet, $14 \%$ morning time, $21 \%$ afternoon, $52 \%$ evening and $13 \%$ at night. The devices used to practice and connect in social media are $83 \%$ smartphone, $11 \%$ laptop, 3\% desktop and 3\% tablet. The Arab population is considered youthful, since $0.33 \%$ of each Arabic country is measured about 25 years old or younger. The majority is youth, as per June 2016, $77 \%$ of social media users were between 16 and 34 years old $1^{1}$ and percentage of Facebook users reached $67 \%$ as soon as uses are between 15 and 29 years old. ${ }^{2}$

Many other forms of social media used by Arab countries are considered very important tools to E-commerce and E-marketing. (E.g. Apple iTunes, click2quit, Asmallworld.net, E-Bay, Amazon.com, Craig's list, current TV, Open source software communities like Mozilla, windows live, yahoo, google, etc.) [33].

The main support of Social Media in Marketing Communication crossing all the Arab regions are: communication, knowledge and entertainment [34]. The values of sowing knowledge, experience, patience and morality so that the society can reap promising young leadership and change the destiny of Lebanon (Farhat, 2017).

Communication. Social media flat the Arab world and reduce distances. Through it, people are becoming closer. Improving and offering users clear meaning of communication reduce geographical and cultural borders and limitations across Arab countries in different continents [2].

Knowledge. Social media networks opens horizons and prospects in knowledge and novel understanding. It helps people to develop and research topics that are interested in. knowledge is well considered as a modern technological tool for receiving and instant update and modernization [35].

Entertainment. In Arab continent, [36] states that social media is seeming as a basis of entertainment helping to break the wearisomeness of regular repetitive. It allows operators to lookout and lookout missing programs or chapters, online sport events besides all entertainment shows.

Social Broadcasting in Publicizing Communication has become interesting due to the quick technology's changes and modifications [10]. Communication channels are becoming multiple and consumers can change their preferences media uses for information [37]. The effectiveness of this communication depends on the well understanding of consumer needs and behavior by identifying their needs and provides them with the correct service at the accurate time in the precise place [38]. It is very important to make sure that the appropriate media is used [39]. Multiple channels of communication networks in Arab regions pose a big challenge to Arabic Marketers to reach their target consumers especially that traditional marketing media is losing its importance by challenging with the novel social media.[9]. Internet networks are rising and increasing such radio, online newspapers, online magazine and TV as a preferred platform for advertisement [40].

Social media presence in marketing communication is rising and growing rapidly and faster, becoming a big part of marketing planning and strategy of companies considering volume, size, shape and purpose [31]. All Arab marketers try to assimilate Integrated Marketing Communication (IMC) in order to guide principles and practice them to communicate with their target market. [41] suggests that IMC use to coordinate advertising and control public relations, direct marketing and personnel selling. It helps to achieve different company's missions and goals [42].

\footnotetext{
${ }^{1}$ Go-Gulf.2013. «Social media in the middle East» statistics and trends.

${ }^{2}$ Mohammed Bin Rashid School of Government. 2014. «Citizen Engagement and Public Services in the Arab World: The Potential of Social Media». 6th Edition. (http://www.go-gulf.ae/blog/social-media-middle-east. 
Moreover, [43] suggests that social media network communication is an economical tool, using Line, Instagram, Twitter, WhatsApp, Viber, Facebook, LinkedIn and others [44]. Therefore, using text message and voice calls will stand and sustain significant telecommunication costs to consumer [45]. Social media still the main platform in the Arab countries, where users can express and show their creativity and inspiration. It enables freedom of expressions and direct contact [41]. It reinforces the need of Arab youth to escape from closed society become more sociable. In e-marketing, social media allowed to find professional information for career opportunities through networks and opens occasions in the Arab world to have and maintain their own businesses [46] e.g. it empowers women to work online business at home.

Social Media in Marketing Communication in Arab countries. Arab marketers recognize that digital marketing and online investment are primordial and elemental to development and implement e-marketing [47]. Companies who desires to finance by investing in digital social such television, broadcasting, radio, etc. must firstly select media choices and customer preferences with a digital infrastructure [48]. Business webpages are the greatest often used numerical announcement network (90\% of Arabic defendants), tracked by social networking sites like Facebook (73\% and more), LinkedIn (46\%), and Twitter (42\%) [27]. Digital marketing expenses and costs presently characterize approximately $21 \%$ of the total budget among companies $[49,50]$. These expenditures will remain in growing and rising, as $78 \%$ of companies report an purpose to rise asset in digital elevation in the little period [51].

A comparison in Table 3 will demonstrate and indicate information about many classifications concerning Arabic countries. The top social media channel used in Arab country is Facebook. About $45 \%$ of users ensure that Facebook has the preference on other social media tools in Arab countries. Statistics concerning the access on Facebook are presented in Chart 1.

Table 3 - Comparison table concerning Arabic countries

\begin{tabular}{|c|c|c|c|c|c|c|c|c|}
\hline & 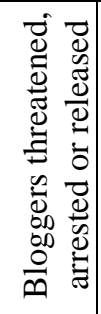 & 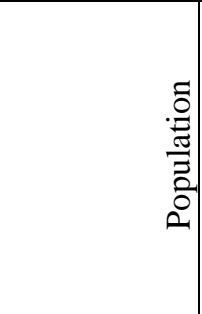 & 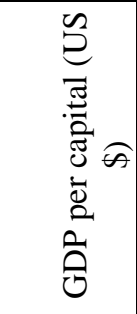 & 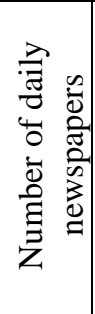 & 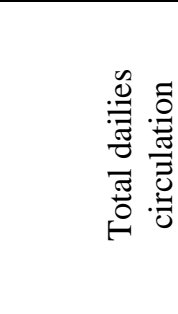 & 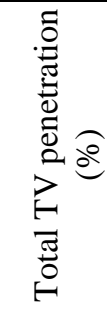 & 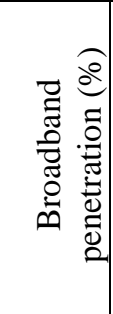 & 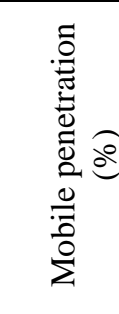 \\
\hline Bahrain & 5 & 800,000 & 27,260 & 9 & 189,000 & 98.0 & 68.0 & 209.0 \\
\hline Egypt & 31 & $76,700,000$ & 2,160 & 19 & $4,000,000$ & 93.0 & 7.4 & 72.0 \\
\hline Jordan & 1 & $5,900,000$ & 3,630 & 8 & 313,000 & 95.0 & 15.0 & 95.0 \\
\hline Kuwait & 2 & $3,500,000$ & 45,920 & 17 & 961,000 & 99.0 & 25.0 & 109.0 \\
\hline Lebanon & 5 & $3,900,000$ & 7,710 & 13 & 396,000 & 93.4 & 19.0 & 61.0 \\
\hline Oman & 0 & $2,800,000$ & 21,650 & 8 & 274,000 & 86.0 & 9.7 & 130.0 \\
\hline PalestinianTerritory & 1 & $4,000,000$ & 1,680 & 4 & 80,000 & 93.0 & 15.0 & 25.0 \\
\hline Qatar & 0 & $1,200,000$ & 93,170 & 7 & 211,000 & 93.5 & 84.0 & 169.0 \\
\hline Saudi Arabia & 6 & $25,500,000$ & 18,850 & 15 & $1,900,000$ & 91.0 & 37.0 & 130.0 \\
\hline Syria & 16 & $20,300,000$ & 2,770 & 10 & 379,000 & 90.0 & 0.5 & 45.0 \\
\hline Yemen & 3 & $23,700,000$ & 1,170 & 6 & 170,000 & 61.0 & 1.6 & 34.0 \\
\hline
\end{tabular}

Source: United Nation ILO Department of statisics,http://laborsta.ilo.org.

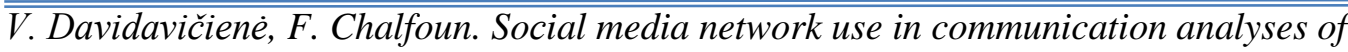


Facebook is providing to Arab communities fastly and highly among all others live social networks online. It views for many explanations: it successes easily, the quality is available, and information is well identified. For researchers and scientists, Facebook is interesting in many aspects:

1) As a form of social media phenomenon;

2) As an single space of remark on the confidentiality approaches and the designs of information disclosure between fresh individuals users (Figure 1).

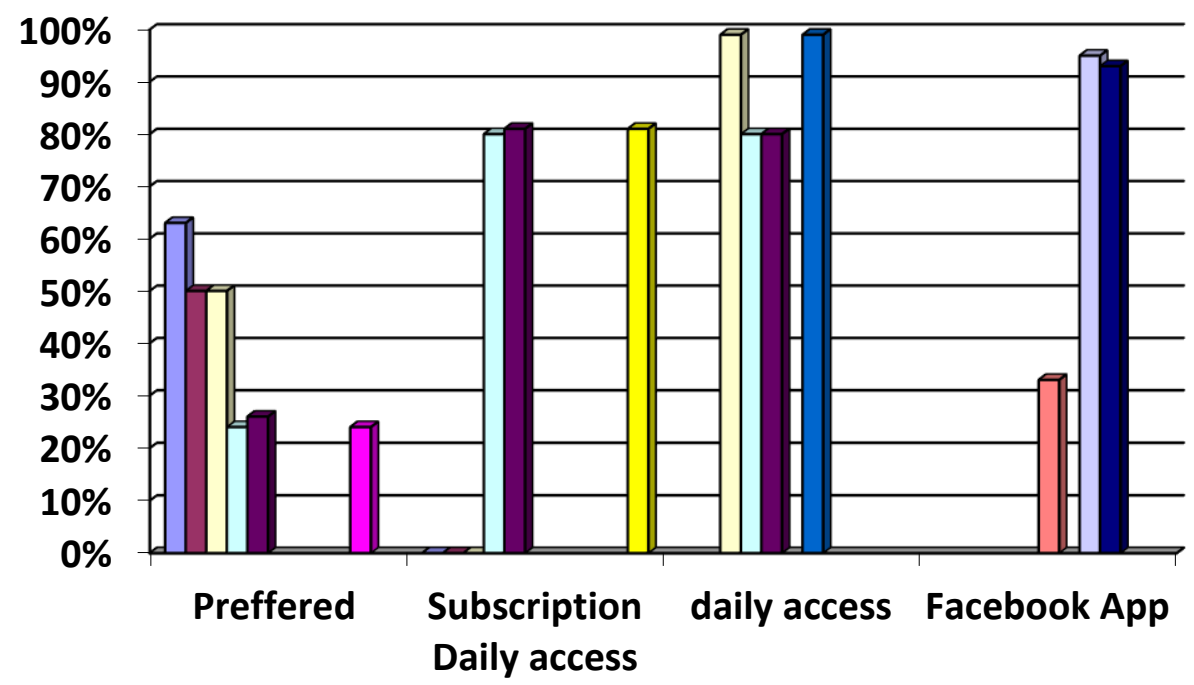

\begin{tabular}{|l|}
\hline$\square$ Jordan \\
$\square$ Libya \\
$\square$ Palestine \\
$\square$ Ksa \\
$\square$ Bahrain \\
$\square$ Kuwait \\
$\square$ Irak \\
$\square$ Syria \\
$\square$ Egypt \\
$\square$ Lebanon \\
$\square$ Quatar \\
\hline
\end{tabular}

Figure 1 - Social media use by country

Analysis of the Differences between Lebanon and some Arab countries. The four best social media networks (Facebook, Twitter, Instagram and LinkedIn) are used for marketing communication by the following countries which are involved in this research.

The Table 4 shows the list of subscribers of these four social media networks in 2017 displaying the result of comparison between Lebanon and Arab countries.

Table 4 - Lebanon-Arab countries (Subscribers on the four social media networks (2017)

\begin{tabular}{|c|c|c|c|c|}
\hline & Facebook & Instagram & Twitter & LinkedIn \\
\hline Lebanon & $\mathbf{3 , 1 0 0 , 0 0 0}$ & $\mathbf{5 7 0 , 0 0 0}$ & $\mathbf{2 0 0 , 0 0 0}$ & $\mathbf{2 1 5 , 0 0 0}$ \\
Bahrain & $1,000,000$ & 140,000 & 200,000 & 236,000 \\
Egypt & $14,000,000$ & 800,000 & $1,700,000$ & $2,420,000$ \\
Iran & $17,200,000$ & No Data & No Data & No Data \\
Iraq & $14,000,000$ & 100,000 & 400,000 & 506,000 \\
Jordan & $4,800,000$ & 260,000 & 200,000 & 556,000 \\
Kuwait & $2,300,000$ & 360,000 & 500,000 & 451,000 \\
Oman & $1,500,000$ & 290,000 & 200,000 & 340,000 \\
Palestinian & $1,700,000$ & 340,000 & 300,000 & 143,000 \\
Territory & $2,200,000$ & 240,000 & 200,000 & 565,000 \\
Qatar & $18,000,000$ & $2,100,000$ & $1,700,000$ & $2,510,000$ \\
Saudi Arabia & $6,000,000$ & 66,000 & 300,000 & 155,833 \\
Syria & $2,000,000$ & 37,000 & 100,000 & 152,000 \\
Yemen & Arab World & & & \\
\hline
\end{tabular}

Source: Arab World-statistics Feb 2017 - WEEDOO 
Facebook is the first much known social media stage with around $156,000,000$ by early 2017 , it is up from $115,000,000$ a year early. It raised up to $39 \%$ from $28 \%$. Generally, Arabic language is becoming the main on Facebook within the Arab region. While many people continue using multiple languages on posting and reading social media materials. In the other hand, Instagram has reached about 7,100,000 users in 2017. The penetration is about $1.8 \%$ overall. The dominant language is English for 55\%. Meanwhile Arabic has $37 \%$ share. Twitter access by Arab countries has reached 11,100,000 users. Almost rising up from 5,800,000 three years ago. The Arab world generates 27,400,000 tweets per day. It is approximately up from 17,200,000 tweets per day two years early. The total number of LinkedIn has reached $16,600,000$ on January 2017. It is a remarkable growth of about $22 \%$ a year early. At the end Female users in the Arab regions constitute about $28 \%$ of all LinkedIn users. This percentage has been mostly statics over the past two years.

Conclusions from this research and prospects for further developments in this area. A real opportunity to continuously improve the understanding, improvement and technology collection is the status of a complex adaptive system technology attribution. Thus, Social Media Network in communication is growing up throughout 2017 in technology and status [52]. It is playing a critical role in changes sweeping Arab countries. Governments and businesses have notice of the big potential offered by the increased penetration of social network channels and tools. This article focuses on large social media engagement through communication and information technology in the Arab countries.

The impact of the Social Media Networks is remarkable on all aspects of life. People are using it to connect, communicate, trade, join and transfer information. It unites users with common interests and benefits. The four most used in Arab countries are: Instagram, Facebook, twitter, and LinkedIn. It has been perceived in this article that Facebook is the most and first principal social networking used in the main mentioned Arabic countries and Twitter is wild gaining the market.

This reading determines that the advance of social media networks sites in Arabic region appears brighter as a novel public network. Users seems also constantly and continually increasing and growing surrounding users of all ages and social circumstances.

This article also studied the potential of Social Network Applications to increase the collaboration, knowledge, sharing and innovation between users, entities and all sectors. The subject defined overhead gives an on-going discussion around social media significance for users and researchers; methodologically a researcher's abilities about claims and rights still remain to be explored. Because it is incomplete by an absence of long studies. World is speedily moving and scholar users may still have a limited understanding about using social media to maintain efficiency and effectiveness in their work, study or business. Such interrogations and requires will necessitate significant quantitative and qualitative research.

Finally, this study may help to form a basis for further and upcoming investigations researches and other significant subjects close Social Media Networks use in Communication, Analyses of Arabic countries.

1. O'Keeffe, GS \& Clarke-Pearson, K. (2011). The Impact of Social Media on Children, Adolescents, and Families. Pediatrics. 127:800-804.

2. Baruah, TD. (2012). Effectiveness of Social Media as a tool of communication and its potential for technology enabled connections: A micro-level study. Int. J. Sci. Res. Publ. 2:1-10.

3. Liu, J, Dai, R, Wei, X (David), \& Li, Y. (2016). Information revelation and customer decisionmaking process of repeat-bidding name-your-own-price auction. Decis. Support Syst. 90:46-55.

4. Collin, P, Rahilly, K, Richardson, I, \& Third, A. (2011). Literature Review: The Benefits of Social

$\bar{V}$. Davidavičienè, F. Chalfoun. Social media network use in communication analyses of 
Networking Services.:29. Retrieved from http://www.fya.org.au/wp-content/uploads/2010/07/TheBenefits-of-Social-Networking-Services.pdf.

5. Shabir, G, Mahmood, Y, Hameed, Y, Safdar, G, Farouq, SM, \& Gilani, S. (2014). The Impact of Social Media on Youth: A Case Study of Bahawalpur City. Asian J. Soc. Sci. Humanit. 3:132-151.

6. Reimer, T, \& Benkenstein, M. 2016. When good WOM hurts and bad WOM gains: The effect of untrustworthy online reviews. J. Bus. Res. 69:5993-6001.

7. Ybarra, ML, Espelage, DL, \& Mitchell, KJ. (2007). The Co-occurrence of Internet Harassment and Unwanted Sexual Solicitation Victimization and Perpetration: Associations with Psychosocial Indicators. J. Adolesc. Heal. 41.

8. Mahmud, M, Akram, Z, Mahmud, M, \& Mahmood, A. (2015). Impact of Social Networking Sites (Snss) No Youth. Appl. Sci. Reports. 11:6-10.

9. Chen, CC, Shih, SY, \& Lee, M. (2016). Who should you follow? Combining learning to rank with social influence for informative friend recommendation. Decis. Support Syst. 90:33-45.

10. Conole, G, Galley, R, \& Culver, J. (2011). Frameworks for understanding the nature of interactions, networking, and community in a social networking site for academic practice. Int. Rev. Res. Open Distance Learn. 12:119-138.

11. Agatston, PW, Kowalski, R, \& Limber, S. (2007). Students' Perspectives on Cyber Bullying. J. Adolesc. Heal. 41:59-60.

12. Osterrieder, A. (2013). The value and use of social media as communication tool in the plant sciences. Plant Methods. 9:26.

13. Ellison, NB, Steinfield, C, \& Lampe, C. (2007). The benefits of facebook 'friends:' Social capital and college students' use of online social network sites. J. Comput. Commun. 12:1143-1168.

14. Bik, HM, \& Goldstein, MC. (2013). An Introduction to Social Media for Scientists. PLoS Biol. 11. 15. Priem, J, Piwowar, Ha, Hemminger, BH, Jason, Priem, \& Heather, A. (2011). Altmetrics in the wild: An exploratory study of impact metrics based on social media. Metrics 2011 Symp. Informetr. Scientometr. Res. New Orleans, LA, USA.:1-18. doi:http://arxiv.org/abs/1203.4745v1.

16. Er, G, Rossi, F, Paristech, T, Aufaure, M, Paris, EC, Kuntz, P, Buffa, M, \& Antipolis, S. (2011). Semantic Social Network Analysis. Unknown.:1-5.

17. Hargittai, E. (2007). Whose space? differences among users and non-users of social network sites. J. Comput. Commun. 13:276-297.

18. McClain, C, \& Neeley, L. (2015). A critical evaluation of science outreach via social media: its role and impact on scientists. F1000Research. doi:10.12688/f1000research.5918.2.

19. Acquisiti, A, \& Gross, R. (2006). Imagined communities:awareness, information sharing, and privacy on the Facebook. Int. Work. Priv. Enhancing Technol. Springer, Berlin.:36-58. doi:10.1007/11957454_3.

20. Backstrom, L, Huttenlocher, D, Kleinberg, J, \& Lan, X. (2006). Group formation in large social networks. 12th ACM SIGKDD Int. Conf.:44-54. doi:10.1145/1150402.1150412.

21. Stam, K, Chao, M-Y, Dong, S, Liu, Y, Cameron, G, \& Stam, A. (2010). Sociometric Attractiveness on Facebook. Proc. Int. Conf. Inf. Manag. Eval.:371-379.

22. Dwyer, C, Hiltz, SR, \& Passerini, K. (2007). Trust and privacy concern within social networking sites: A comparison of Facebook and MySpace. Am. Conf. Inf. Syst. 123:339-350.

23. Golder, SA, Wilkinson, D, \& Huberman, BA. (2007). Rhythms of Social Interaction: Messaging Within. Proc. Third Communities Technol. Conf.:41-66. Retrieved from https://books.google.com. br/books?hl=en\&lr=\&id=HFa7AeNIYtUC\&oi=fnd\&pg=PA40\&ots=wUFn-m-_1L\&sig=Q3g6c_ uwL_ORyydKWLHHIlxLZzk.

24. Hogan, B. (1996). Analysing Social Networks Via the Internet. Soc. Networks. 46:141-160.

25. Wang, Y, Wang, N, Jiang, L, Yang, Z, \& Cui, V. (2016). Managing relationships with power advantage buyers: The role of supplier initiated bonding tactics in long-term buyer-supplier collaborations. J. Bus. Res. 69:5587-5596.

26. Rakthin, S, Calantone, RJ, \& Wang, JF. (2016). Managing market intelligence: The comparative role of absorptive capacity and market orientation. J. Bus. Res. 69:5569-5577.

27. Chen, R, Sharma, SK, \& Raghav Rao, H. (2016). Members' site use continuance on Facebook: Examining the role of relational capital. Decis. Support Syst. 90:86-98. 
28. Ceric, A, D’Alessandro, S, Soutar, G, \& Johnson, L. (2016). Using blueprinting and benchmarking to identify marketing resources that help co-create customer value. J. Bus. Res. 69:5653-5661.

29. Siddiqui, S, \& Singh, T. (2016). Social Media its Impact with Positive and Negative Aspects. Int. J. Comput. Appl. Technol. Res. 5:71-75.

30. O'Shannassy, T, \& Leenders, MAAM. (2016). Avoiding the 'too comfortable in the saddle' syndrome: Obtaining high performance from the chairperson, CEO and inside directors. J. Bus. Res. 69:5972-5982.

31. Wessel, M, Thies, F, \& Benlian, A. (2016). The emergence and effects of fake social information: Evidence from crowdfunding. Decis. Support Syst. 90:75-85.

32. Kowalski, RM, \& Limber, SP. (2007). Electronic Bullying Among Middle School Students. J. Adolesc. Heal. 41:22-30.

33. Winkler, M, Abrahams, AS, Gruss, R, \& Ehsani, JP. (2016). Toy safety surveillance from online reviews. Decis. Support Syst. 90:23-32.

34. Guido, G, Pichierri, M, Nataraajan, R, \& Pino, G. (2016). Animated logos in mobile marketing communications: The roles of logo movement directions and trajectories. J. Bus. Res. 69:6048-6057.

35. Athreye, S, Batsakis, G, \& Singh, S. (2016). Local, global, and internal knowledge sourcing: The trilemma of foreign-based R\&D subsidiaries. J. Bus. Res. 69:5694-5702.

36. Godey, B, Manthiou, A, Pederzoli, D, Rokka, J, Aiello, G, Donvito, R, \& Singh, R. (2016). Social media marketing efforts of luxury brands: Influence on brand equity and consumer behavior. J. Bus. Res. 69:5833-5841.

37. Takata, H. (2016). Effects of industry forces, market orientation, and marketing capabilities on business performance: An empirical analysis of Japanese manufacturers from 2009 to 2011. J. Bus. Res. 69:5611-5619.

38. Yoo, J, \& Park, M. (2016). The effects of e-mass customization on consumer perceived value, satisfaction, and loyalty toward luxury brands. J. Bus. Res. 69:5775-5784.

39. Kaufmann, HR, Petrovici, DA, Filho, CG, \& Ayres, A. 2016. Identifying moderators of brand attachment for driving customer purchase intention of original vs counterfeits of luxury brands. J. Bus. Res. 69:5735-5747.

40. Feuerriegel, S, \& Prendinger, H. (2016). News-based trading strategies. Decis. Support Syst. 90:65-74.

41. Zeitel-Bank, N, \& Tat, U. (2014). Social media and its effects on individuals and social systems. Manag. Knowl. Learn. Int. Conf.:1183-1190. Retrieved from http://www.toknowpress.net/ISBN/978961-6914-09-3/papers/ML14-714.pdf.

42. Oakleaf, M. (2009). Writing information literacy assessment plans: A guide to best practice. Commun. Inf. Lit. 3:80-90.

43. Xue, J, Yuan, H, \& Shi, B. (2016). Investigating partners' opportunistic behavior in joint ventures in China: The role of transaction costs and relational exchanges. J. Bus. Res. 69:6067-6078.

44. Willard, NE. (2007). The Authority and Responsibility of School Officials in Responding to Cyberbullying. J. Adolesc. Heal. 41:64-65.

45. Williams, J, Ashill, N, \& Thirkell, P. (2016). How is value perceived by children? J. Bus. Res. 69:5875-5885.

46. Ybarra, ML, Diener-West, M, \& Leaf, PJ. (2007). Examining the Overlap in Internet Harassment and School Bullying: Implications for School Intervention. J. Adolesc. Heal. 41:42-50.

47. Sawyer, R. (2011). The Impact of New Social Media on Intercultural Adaptation. Digit. Commons.:1-30. doi:10.1111/j.1548-1379.2010.01107.x.

48. Becker, JU, Clement, M, \& Nöth, M. (2016). Start-ups, incumbents, and the effects of takeover competition. J. Bus. Res. 69:5925-5933.

49. Miao, C, Yu, H, Shen, Z, \& Leung, C. (2016). Balancing quality and budget considerations in mobile crowdsourcing. Decis. Support Syst. 90:56-64.

50. Tiago, MTPMB, \& Veríssimo, JMC. (2014). Digital marketing and social media: Why bother? Bus. Horiz. 57:703-708.

51. Ashraf, AR, Razzaque, MA, \& Thongpapanl, N (Tek). (2016). The role of customer regulatory

$\bar{V}$. Davidavičienè, F. Chalfoun. Social media network use in communication analyses of 
orientation and fit in online shopping across cultural contexts. J. Bus. Res. 69:6040-6047.

52. Marsden, JR, George, T, \& Baldassarre, MT. (2017). Editorial Board. Account. Forum. 41.

В. Давідавічене, д-р екон. наук, професор, завідувач кафедри бізнес-технологій та підприсмництва Вільнюського технічного університету імені Гедимінаса (Вільнюс, Литва)

Ф. Шалфун, магістр з менеджменту кафедри бізнес-технологій та підприємництва, Вільнюського технічного університету імені Гедимінаса (Вільнюс, Литва)

\section{Використання соціальних мереж в аналізі комунікацій арабських краӥн}

Розвиток сочіальних мереж змінює способи спілкування, співпраиі, створення та споживання. Соџіальні мережі стають фундаментальними та мають трансформаційний вплив на бізнес і компанії. Використання інструментів соџіальної мережі та стимулювання інновацій у взаєминах із покупцем та потенційним клієнтом допомагає підвищити рівень спілкування та взасмодії. Метою даної статті є аналіз, виявлення та демонстрація всіх особливостей використання соиіальних мереж в арабських краӥнах. Використовуються методи аналізу наукової літератури, аналізу крос-таблиць та порівняльного аналізу.

Ключові слова: соціальні медіа, цифрові медіа, маркетингові комунікації, соціальні мережі.

Received to the editor April 6, 2018 